\title{
BENTUK KIGO PADA HAIKU DAN ISI SINDIRAN PADA SENRYU OLEH MAHASISWA SASTRA JEPANG UNIVERSITAS BRAWIJAYA
}

\author{
Oleh: \\ Fitriana Puspita Dewi, Elizabeth Worobroto, Santi Andayani* \\ Fakultas Ilmu Budaya Universitas Brawijaya
}

\begin{abstract}
In the Japanese literature, poetry has its own type and form, including Haiku and Senryu with 5-7-5 syllabic structure. Another prominent characteristic of Haiku is the topic concerning beauty of nature and the elements like Kigo or Kisetsu no Kotoba (the words marking the seasons) in which it shows the closeness of Japanese people with nature. Senryu has humorous and witty elements, including satire and the story about people; it does not describe season at all. Therefore, cultural background and social condition of society will affect content and form of the satire.

This research aims to analyze the form of kigo in haiku and the content of satire in senryu, written by students of Japanese Literature in Brawijaya University. This research used qualitative descriptive methodology. The research shows the result that kigo ame and kigo taiyou are the most frequently used forms. In senryu, the contents of satire are love, student life, and physical depiction.
\end{abstract}

Keyword: kigo, fudo, haiku, senryu, satire

\section{PENDAHULUAN}

Puisi merupakan bentuk karya sastra yang mengekspresikan secara padat pemikiran danperasaan penyairnya yang digubah dalam wujud dan bahasa yang berkesan. Hal ini senada dengan apa yang diungkapkan oleh Pradopo (2012 : 11) bahwa puisi merupakan hasil aktivitas pemadatan, yaitu proses penciptaan dengan cara menangkap kesan-kesan lalu memadatkannya (kondensasi). Secara sederhana, puisi terdiri atas beberapa unsur seperti kata, larik, bait, bunyi, dan makna. Kemudian, untuk jenis puisi sendiri dibedakan menjadi puisi lama dan puisi baru. Puisi lama terikat oleh aturanaturan tertentu, seperti jumlah kata dalam 1 baris, jumlah baris dalam 1 bait, persajakan (rima), banyak suku kata tiap baris dan irama, sedangkan puisi baru bentuknya lebih bebas, tidak terikat oleh aturan.

${ }^{*}$ Penulis Korespondensi.

E-mail: santi_anda@yahoo.co.id
Dalam kesusastraan Jepang, puisi juga memiliki jenis dan bentuknya masingmasing. Beberapa bentuk puisi Jepang antara lain waka (Syair Jepang), tanka (syair pendek), haiku dan senryu. Haiku dan senryu adalah jenis puisi Jepang yang muncul dan berkembang pada zaman Edo (1600-1867). Haiku dan senryu adalah puisi lama yang memiliki aturan jumlah suku kata 5-7-5, atau 5 suku kata pada larik pertama, 7 suku kata pada larik kedua, dan 5 suku kata pada larik ketiga. Yang membedakan antara Haiku dan senryu adalah isinya. Jika Haiku berbicara tentang keindahan alam maka senryu berisi tentang sindiran akan kehidupan manusia (Mandah, dkk., 1983 : 6-7).

Haiku memiliki unsur-unsur yaitu kigo atau kisetsu no kotoba (kata-kata penanda musim), terdapat kireji (huruf pemotong) seperti ya dan kana untuk menunjukkan adanya jeda atau pergantian topik. Kigo adalah unsur yang paling penting dan menonjol dalam haiku karena 
menunjukkan kedekatan orang Jepang terhadap alam. Misalnya, untuk menyimbolkan bahwa puisi itu dibuat kala musim semi maka kata-kata seperti bunga sakura, ume (plum blossom), hanami (kegiatan menikmati keindahan bunga Sakura) akan muncul di dalamnya. Pada musim panas kigo yang muncul misalnya furin (lonceng kecil), semangka, laut/ pantai, belut, burung Hototogisu. Kemudian pada musim gugur misalnya akan muncul katakata seperti momiji (daun mapple yang berubah warna) serta bulan, dan pada musim dingin kigo yang muncul misalnya salju, daruma, angsa, tahun baru, dan lain-lain.

Selain haiku, jenis puisi Jepang kuno lainnya yang terkenal adalah senryu. Berbeda dari haiku, senryu memiliki aturan yang agak lentur yaitu tidak harus menyebutkan kigo di dalam penulisannya. Senryu harus mengandung unsur bersifat lucu dan jenaka, berisi sindiran, bercerita tentang rakyat dan tidak menggambarkan musim sama sekali (Asoo, 1983: 134).Aturannya sama dengan haiku yaitu bersuku kata 5, 7, 5 atau sebanyak 17 suku kata. Contoh senryu yaitu:

\section{Ohanage wo kazoete iru ga tsutome nari \\ Pekerjaannya sekarang hanya menghitung bulu hidung tuannya.}

Senryu di atas berisi sindiran terhadap kalangan samurai di zaman Edo. Pada zaman Edo, kalangan samurai menjadi kelas masyarakat yang paling atas. Akan tetapi, karena pada masa itu tidak ada peperangan maka samurai tidak banyak bekerja. Tugas samurai hanya mengabdi sepenuhnya kepada atasannya yaitu para daimyo. Bukti pengabdian itu dijadikan sindiran yaitu dengan kata "menghitung bulu hidung tuannya”, menyiratkan pekerjaan yang tidak penting tapi tetap dilakukan demi loyalitas. Puisi jenis ini bisa digolongkan dalam puisi jenis satire atau kritik sosial. Topik yang dijadikan bahan sindiran pun beragam seperti kehidupan suami-istri, menyindir atasan, sindiran terhadap kelas masyarakat tertentu dan lain sebagainya. Latar belakang budaya dan kondisi sosial masyarakat tentu sangat mempengaruhi isi dan bentuk sindiran.

Ketika mahasiswa Indonesia ditugaskan untuk membuathaiku dansenryu, isi dan topik haiku dan senryu yang mereka buat sangat berbeda dengan yang dibuat oleh orang Jepang. Meskipun mereka sudah memiliki konsepsi budaya Jepang tapi latar belakang asli budaya Indonesia lebih mendominasi. Alam Indonesia yang hanya terdiri dari dua musim yaitu musim hujan dan kemarau sangat mempengaruhi pilihan kata tentang alam pada haiku yang dibuat oleh mahasiswa Indonesia. Tak ada kata penanda musim yang spesifik pada haiku yang dibuat mahasiswa Indonesia. Begitu pula isi dan cara menyindir yang mereka tuangkan pada senryujuga berbeda dengan yang dibuat oleh orang Jepang.

Dari pemaparan di atas terlihat bahwa latar belakang sosial dan budaya sangat mempengaruhi pilihan kata seseorang ketika membuat puisi, dalam hal ini puisi Jepang yaitu haiku dan senryu. Tidak hanya aspek budaya saja, tapi juga alam sangat mempengaruhi pemikiran masyarakat dimana nantinya aspek ini akan tercermin pada karya sastra yang dihasilkan oleh masyarakat tersebut.Oleh karena itu, meskipun dalam teorinya, para mahasiswa telah diberikan pemahaman mengenai aturan dalam penulisan puisi Jepang yaitu haiku dan senryu, namun dalam praktiknya karya yang mereka buat seperti pada haiku masih banyak yang menunjukkan ciri khas alam Indonesia dan pada senryu, isi sindiran yang mereka pergunakan pun sedikit lain dari nuansa senryu Jepang pada umumnya. Berdasarkan hal tersebut, maka yang menjadi bahasan dalam penelitian ini adalah bentuk kigo yang terdapat dalam haiku dan isi sindiran yang terdapat dalam senryu yang dibuat oleh mahasiswa sastra Jepang semester IV Universitas Brawijaya.

Oleh karena adanya perbedaan budaya antara Jepang dan Indonesia, maka penelitianinibertujuanuntukmengetahuibentu kkigo yang terdapatdalamhaiku dan isisindiran yang terdapatdalamsenryu yang dibuat oleh orang Indonesia dalam hal ini adalah mahasiswasastra Jepangsemester IV UniversitasBrawijaya. 
Tersedia online di http://ejournal.undip.ac.id/index.php/izumi

\section{METODE PENELITIAN}

Penelitian ini menggunakan metode deskriptif kualitatif. Pengumpulan data dilakukan dengan metode pustaka. Sumber data primer diperoleh dari tugas mahasiswa yang mengambil mata kuliah Sejarah Kesusasteraan Jepang dan data sekunder diperoleh melalui buku-buku yang mendukung penelitian. Subyek penelitian adalah mahasiswasastraJepangsemester IV Universitas Brawijaya angkatan 2013.

Langkah-lagkah

penelitian

dilakukan dengan cara : (1) Pemberian materi kuliah berupa sejarah munculnya haiku dan senryubeserta contoh karyanya dari beberapa penyair terkenal masa itu; (2) Pemberian tugas secara spontanitas kepada para mahasiswa untuk membuat haiku dan senryu dan menyuruh mereka untuk membacakannya di depan kelas guna mengetahui tingkat pemahaman mereka ; (3) Tugas yang terkumpul dilakukan pemilahan dan penyusunan data berupa haiku dan senryu; (4) Penyuntinganhaiku dan senryudan pemberian kode untuk memudahkan dalam kinerja analisis data; (5) Pengkonfirmasian data dan analisis data berupa pengecekan bentuk kigo pada haiku danisi sindiran pada senryu yang dibuat oleh mahasiswa.

\section{PEMBAHASAN}

Penelitian ini dilakukan di 5 kelas yang mengambil mata kuliah Sejarah Kesusasteraan Jepang dengan total jumlah mahasiswa sebanyak 125 orang. Untuk mengetahui kecenderungan kigo yang digunakan oleh para mahasiswa dalam tugasnya membuat haiku maka analisis dilakukan dengan cara mengakategorisasikan haiku para mahasiswa berdasarkan penggolongan diksi kigosecara umum dan kigoberdasarkan pembagian 4 musim. Kemudian, untuk mengetahui kecenderungan isi sindiran yang terdapat dalam senryuyang dibuat oleh para mahasiswa, maka analisis dilakukan dengan mengkategorisasikan senryu berdasarkan temanya.

\subsection{BentukKigo dalam Haiku yang Dibuat oleh Mahasiswa Sastra Jepang Semester IV Universitas Brawijaya}

Berikut adalah tabel pengakategorisasian haiku yang dibuat oleh 125 mahasiswa berdasar pemilihan diksi kigo secara umum.

\begin{tabular}{|c|c|c|c|c|c|c|c|}
\hline no & kigo & jumlah & prosentase & No & kigo & jumlah & Prosentase \\
\hline 1 & Ame & 28 & 22.4 & 16 & Hoshi & 3 & 2.4 \\
\hline 2 & Kaze & 15 & 12 & 17 & Arashi & 2 & 1.6 \\
\hline 3 & Haru & 8 & 6.4 & 18 & Fuyu & 2 & 1.6 \\
\hline no & kigo & jumlah & prosentase & No & kigo & jumlah & Prosentase \\
\hline 4 & Sora & 7 & 5.6 & 19 & Midori & 2 & 1.6 \\
\hline 5 & Taiyou & 7 & 5.6 & 20 & Nami & 2 & 1.6 \\
\hline 6 & Yuki & 4 & 3.2 & 21 & $N i j i$ & 2 & 1.6 \\
\hline 7 & Yama & 4 & 3.2 & 22 & $A k i$ & 2 & 1.6 \\
\hline 8 & Mushi & 4 & 3.2 & 23 & Taki & 2 & 1.6 \\
\hline 9 & Tsuki & 4 & 3.2 & 24 & Mizu & 1 & 0.8 \\
\hline 10 & Sakura & 4 & 3.2 & 25 & Himawari & 1 & 0.8 \\
\hline 11 & Natsu & 4 & 3.2 & 26 & Kusa & 1 & 0.8 \\
\hline 12 & Momiji & 3 & 2.4 & 27 & $K i$ & 1 & 0.8 \\
\hline 13 & Kuто & 3 & 2.4 & 28 & Tsuchi & 1 & 0.8 \\
\hline 14 & Hana & 3 & 2.4 & 29 & Ukikanki & 1 & 0.8 \\
\hline 15 & Tsuyu & 3 & 2.4 & 30 & Koyo & 1 & 0.8 \\
\hline & umlah & 101 & 80.8 & \multicolumn{2}{|c|}{ jumlah } & 24 & 19.2 \\
\hline
\end{tabular}


Tabel 1

Dari tabel 1 terlihat bahwa terdapat 30 jenis kigo yang digunakan para mahasiswa dalam haiku-nya dankigo ame (hujan) menjadi kigo yang paling digemari mahasiswa yaitu sebanyak 28 mahasiswa, kigo kaze sebanyak 15 mahasiswa,dankigo haru sebanyak 8 mahasiswa di urutan ketiga.
Untuk lebih mendetailkan analisis, kigo dari tabel 1 dikategorisasi kembali berdasarkan pembagian 4 musim dengan jumlah total 49, seperti yang terlihat pada tabel 2 dan untuk kigo yang tidak masuk dalam 4 musim dimasukkan dalam kategori “random" dengan jumlah total 76, seperti pada tabel 3.

\begin{tabular}{|l|l|l|l|l|l|l|l|}
\hline Haru & Jumlah & Natsu & jumlah & Aki & jumlah & Fuyu & jumlah \\
\hline Haru & 8 & Taiyou & 7 & Tsuki & 4 & Yuki & 4 \\
\hline Sakura & 4 & Mushi & 4 & Momiji & 3 & Fuyu & 2 \\
\hline Hana & 3 & Natsu & 4 & Aki & 2 & & \\
\hline & & Himawari & 1 & Koyo & 1 & & \\
\hline & & Midori & 2 & & & & \\
\hline & 15 & \multicolumn{7}{|c|}{ Total= 49 } & 10 & & 6 \\
\hline
\end{tabular}

Tabel 2

\begin{tabular}{|l|l|l|l|l|l|l|l|l|l|}
\hline Random & Jum & Random & Jum & Random & Jum & Random & Jum & Random & Jum \\
\hline Ame & 28 & Yama & 4 & Hoshi & 3 & Niji & 2 & Kusa & 1 \\
\hline Kaze & 15 & Kumo & 3 & Nami & 2 & Taki & 2 & Ki & 1 \\
\hline Sora & 7 & Tsuyu & 3 & Arashi & 2 & Mizu & 2 & Tsuchi & 1 \\
\hline \multicolumn{10}{|c|}{ Total= 76 } \\
\hline
\end{tabular}

Tabel 3

Dari tabel 2 terlihat bahwa kigo yang berkaitan dengan musim panas (natsu) mendominasi kigo musim lainnya. Pada kigo yang masuk dalam kategori random didiominasi dengan kigo ame dan kigo kaze.

Dari data tersebut dapat dikatakan bahwa bentuk kigo yang digunakan oleh para mahasiswa kebanyakan adalah kigo yang masuk kategori random terutama kigo ame dan kigo kaze.Berikut adalah salah satu contoh haiku mahasiswa dengan kigo ame.

Ame ga furuAnata no koto wo omoidasu

Dikala hujan turun,kuteringat kepadamu

Kigo yang masuk kategori random adalah kigo yang tidak begitu terpengaruh atau tidak masuk dalam salah satu pembagian 4 musim karena kigo-kigo ini jika dilihat dari segi konsep fudotidak hanya didasarkan pada iklim atau cuaca tetapi juga dipengaruhi oleh kondisi topografi. Kigo-kigo tersebut adalah kigo sora, yama, kumo, tsuyu, hoshi, nami, arashi, niji, taki, mizu, kusa, ki, tsuchi, danukikanki.

Selain kategori random, bentuk kigo lainnya yang banyak digunakan adalah kigo natsu, dan dalam kigo natsu sendiri kigo taiyou adalah kigo yang paling banyak dipakai. Berikut adalah contoh haiku-nya.

Hisashi dete saezuru tori ga,asa ni naru

Sinar

mentari

merekah,terdengar kicauan burung,hari telah pagi

Sebagaimana Dilihat dari segi konsep fudo, kigo-kigo seperti ame, kaze, dan taiyou merupakan kigo yang tidak asing bagi para 
Tersedia online di http://ejournal.undip.ac.id/index.php/izumi

mahasiswa karena mereka bisa melihat, merasakan, dan mengalaminya sendiri di Indonesia, dan jika dihubungkan dengan lahirnya sebuah karya sastra yang tidak hanya muncul dari buah pikiran pengarang namun juga terkandung latar belakang budaya dan masyarakat di dalamnya, maka tidaklah mengherankan jika penggunaan diksi kigo-kigo tersebut banyak digunakan oleh mahasiswa karena kedekatannya dengan alam Indonesia.

Kemudian dari kigo 4 musim berikutnya yang banyak digunakan adalah kigo haru jika dibandingkan dengan 2 kigo lainnya yaitu kigo aki dan fuyu. Kigo haru atau musim semi pun dari segi konsep fudo memiliki pemandangan alam yang tidak begitu jauh berbeda dengan istilah 'semi' di Indonesia yang ditandai dengan mekarnya bunga-bunga. Kedekatan ini juga membuat para mahasiswa tidak begitu susah dalam berimajinasi mengenai kondisi dan suasana yang ada pada musim ini.

\subsection{Bentuk dan isi sindiran dalam Senryuyang Dibuat oleh Mahasiswa Sastra Jepang semester IV Universitas Brawijaya}

Berbeda dengan haiku, senryumemiliki ciri khas dalam hal menggambarkan peristiwa. Jika dilihat dari isinya, senryu lebih menitikberatkan masalah kemanusiaan yang awam, perasaan manusia sebagai objek yang dikemas dengan humor namun mengandung sindiran-sindiran yang jenaka.Sindiran-sindiran tersebut dapat ditujukan untuk orang lain atau sekedar menertawakan kebodohan diri sendiri. Tema yang terungkap yang berkaitan dengan gambaran kehidupan mahasiswa khususnya, yang terekam di dalam senryu karya mahasiswa angkatan 2013 dapat dilihat pada tabel berikut ini.

\begin{tabular}{|l|l|l|l|}
\hline NO & TEMA & JUMLAH & PROSENTASE \\
\hline 1 & Cinta & 18 & $14.4 \%$ \\
\hline 2 & Materi & 14 & $11.2 \%$ \\
\hline 3 & Kehidupan Mahasiswa & 9 & $7.2 \%$ \\
\hline 4 & Fisik & 8 & $6.4 \%$ \\
\hline 5 & Laper, Makan, Gendut & 8 & $6.4 \%$ \\
\hline 6 & Kebahagiaan & 7 & $5.6 \%$ \\
\hline 7 & Waria & 7 & $5.6 \%$ \\
\hline 8 & Berisik & 6 & $4.8 \%$ \\
\hline 9 & Politik & 4 & $3.2 \%$ \\
\hline 10 & Kentut & 4 & $3.2 \%$ \\
\hline 11 & Makanan Gratis & 3 & $2.4 \%$ \\
\hline 12 & Random & 18 & $14.4 \%$ \\
\hline 13 & Zonk & 19 & $15.2 \%$ \\
\hline
\end{tabular}

Tabel 4

Dari tabel 4 dapat diketahui bahwa terdapat tema yang banyak menginspirasi mahasiswa dalam penulisan senryu yang menduduki tiga besar yaitu tema cinta sekitar 14.4\% (18 mahasiswa), disusul dengan tema materi 11.2\% (14 mahasiswa), serta kehidupan mahasiswa sekitar 7.2 (9 mahasiswa).

Tema cinta yang diusung oleh para mahasiswa berisikan tentang gambaran kehidupan rekan mahasiswa yang masih single seperti senryu berikut ini,
1) 恋人は う

(Koibito wa kimi ga dekimasen kawaiisou) (Pacar engkau tak bisa mendapatkannya kasihan nya)

atau gambaran tentang mahasiswa yang telah memiliki pasangan namun merasakan sesuatu yang asing satu sama lain.

2) 君に会う話できない残念だ

(Kimi ni au hanashi dekinai zannen da) 
(Bertemu denganmu tak bisa bicara sayang sekali)

Sedangkan senryu yang lain berisikan gambaran tentang bagaimana kehidupan cinta yang telah terjalin dijalani dan bagaimana hati berperan dalam menghadirkan cinta.

$$
\begin{aligned}
& \text { 3) 一人ぼっち一人で食べて それお } \\
& \text { 前のせい }
\end{aligned}
$$

(Hitoribocchi hitori de tabete sore omae no sei)

(Sebatangkara makan sendirian itu karena dirimu)

\section{Dari tema Materi, dapat diketahui bagaimana pendapat mahasiswa tentang pemenuhan materi. Gambaran yang disampaikan oleh mahasiswa tentang materi berkisar tentang bagaimana materi, dalam hal ini uang,menjadi penguasa penting kehidupan manusia. Berikut adalah senryu yang menggambarkan situasi tersebut.}
1) お金なら伺わないで皆好き
(Okane nara utagawanaide minna suki)
(Jika uang jangan ditanya semua suka)

Selain itu ada pula senryu yang menggambarkan tentang bagaimana pentingnya peran materi sebagai pembungkus tampilan.

\section{2）君の服貧乏見たいよ＼cjkstart悪いのよ \\ (Kimi no fuku bimbo mitai yo warui no yo)}

(Bajumu seperti orang miskin jelek nya)

Sedangkan tema ketiga yang banyak mendominasi senryu karya mahasiswa adalah tema tentang kehidupan mahasiswa. Tema ini tentu saja sangat dekat dengan keseharian para mahasiswa. Gambaran kehidupan mahasiswa yang terekam tidak lepas dari masalah perkuliahan, namun ada pula senryu yang jenaka menggambarkan bagaimana sibuknya harus membersihkan tempat tinggal jika ibu berkunjungtiba-tiba di akhirtahun.

Berikut ini adalah senryu yang telah ditulis oleh beberapa mahasiswa yang menggambarkan situasi tersebut di atas.

1) 宿題は考えだけで終わらない

(Shukudai wa kangae dake de owaranai)

(Pekerjaan rumah hanya di pikirkan saja takkan selesai)
Seperti juga haiku yang memiliki unsur-unsur penting di dalam penulisannya, ada 3 hal penting yang harus diperhatikan di dalam pembuatan Senryu. Ketiga hal penting tersebut meliputi : Ugachi (kritikan), Karumi(bentuk), dan Okashimi (humor). Tiga unsur ini merupakan dasar dari teknik penulisan yang harus dipenuhi oleh sebuah senryu. Dengan kata lain, senryu harus memenuhi persyaratan dari segi bentuk yakni jumlah suku kata yang terdiri dari 5-7-5. Bentuk ini akan mendukung isi yang merupakan hasil pengamatan terhadap kehidupan manusia yang di dalamnya mengandung suatu sindiran yang berfungsi sebagai kritikan (Ugachi). Selanjutnya unsur yang merupakan ciri khas dari senryu adalah unsur kejenakaan atau humor (Okashimi).

Humor yang muncul bukanlah merupakan tujuan dari penulisan senryu. Humor ini menjadi aspek yang muncul secara alamiah yang menyatu dengan sindiran yang disajikan.

Dari hasil analisis terhadap karya senryu para mahasiswa, dapat diketahui bahwa para mahasiswa angkatan 2013 secara umum sudah dapat menulis senryu dalam format 5-7-5. Meskipun masih ada sekitar 19 orang $(15.2 \%)$ yang tidak memenuhi syarat dari segi bentuk, namun sekitar $84 \%$ mahasiswa telah dapat memenuhi persyaratan tersebut. Sedangkan dari segi kritikan, para mahasiswa menyampaikannya secara langsung, lugas tanpa membuat suatu perumpamaan. Obyek kritikan diungkapkan langsung disertai ungkapan perasaan dari pengamat atau penulis sendiri. Berikut adalah senryu yang menggambarkan kelangsungan dan kelugasan dari ekspresi pengarang.

$$
\text { そ恋人は 君ができません 可愛 }
$$

(Koibito wa kimi ga dekimasen kawaiisou) (Pacar engkau tak bisa mendapatkannya kasihan nya)

Selain kritikan langsung, ada pula yang menggunakan kritikan tidak langsung. Kritikan tidak langsung yang disampaikan menggunakan teknik perumpamaan yang 
jelas (chokuyu 直喻) atau eksplisit maupun implisit (anyu 暗喻). Ekspresi ini ditandai dengan penggunaan kata mitai, atau you yang berarti seperti atau bagaikan. Berikut contoh senryu yang dimaksudkan.

$$
\begin{aligned}
& \text { 気づいてる＼cjkstart君に話すと＼cjkstart石像のよ } \\
& \text { う }
\end{aligned}
$$

(Ki zuiteiru kimini hanasu to sekizo no you)

(Kusadari bercakap denganmu seperti dengan arca batu)

\section{KESIMPULAN}

Dari hasil analisis diketahui bahwa bentuk kigo yang digunakan oleh para mahasiswa kebanyakan adalah kigo yang masuk kategori random terutama yaitu kigo ame dan kigo kaze. Kigo yang masuk kategori random adalah kigo yang tidak begitu terpengaruh atau tidak masuk dalam salah satu pembagian 4 musim karena kigo-kigo ini jika dilihat dari segi konsep fudotidak hanya didasarkan pada iklim atau cuaca tetapi juga dipengaruhi oleh kondisi topografi. Selain kategori random, bentuk kigo lainnya yang banyak digunakan adalah kigo natsu terutama kigo taiyou dan disusul dengan kigo haru.

Pada senryu,bentuk sindiran yang dibuat oleh mahasiswa bersifat langsung. Sindiran yang bersifat kritikan disampaikan secara lugas baik itu yang bertema cinta, kehidupan mahasiswa maupun tentang penggambaran fisik. Sedangkan isi sindiran disampaikan untuk mengkritik si penulis sendiri dan orang-orang secara umum dan orang-orang terdekat di sekitar kehidupa penulis.

\section{DAFTAR PUSTAKA}

Asoo, Isoji, dkk. 1983. Sejarah Kesusastraan Jepang (Nihon Bungakushi).Jakarta: UI Press.

Mandah, Darsimah, dkk. 1983. Pengantar Kesusastraan Jepang. Jakarta: kerjasama antara Fakultas Sastra UI, The Japan Foundation, dan PT Gramedia Widiasarana Indonesia.
Pradopo, Rachmat Djoko. 2012. Pengkajian Puisi. Yogyakarta : Gadjah Mada University Press 